Article

\title{
Lessons Learned from an Intersectoral Collaboration between the Public Sector, NGOs, and Sports Clubs to Meet the Needs of Vulnerable Youths
}

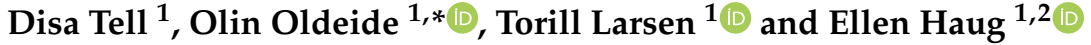 \\ 1 Department of Health Promotion and Development, University of Bergen, Årstadveien 17, \\ 5009 Bergen, Norway; disaat_@hotmail.com (D.T.); torill.larsen@uib.no (T.L.); ellen.haug@uib.no (E.H.) \\ 2 Department of Teacher Education, NLA University College, 5012 Bergen, Norway \\ * Correspondence: Olin.Oldeide@uib.no
}

Citation: Tell, D.; Oldeide, O.; Larsen, T.; Haug, E. Lessons Learned from an Intersectoral Collaboration between the Public Sector, NGOs, and Sports Clubs to Meet the Needs of Vulnerable Youths. Societies 2022, 12, 13. https://doi.org/10.3390/ soc12010013

Academic Editor: Gregor Wolbring

Received: 14 December 2021

Accepted: 14 January 2022

Published: 20 January 2022

Publisher's Note: MDPI stays neutral with regard to jurisdictional claims in published maps and institutional affiliations.

Copyright: (C) 2022 by the authors. Licensee MDPI, Basel, Switzerland. This article is an open access article distributed under the terms and conditions of the Creative Commons Attribution (CC BY) license (https:// creativecommons.org/licenses/by/ $4.0 /)$.

\begin{abstract}
The Norwegian Government emphasizes intersectoral collaboration to achieve health goals such as reducing social health differences. However, research shows that achieving fruitful collaboration between different organizations and the public sector is challenging. The sports sector is one potential partner for such collaboration. Although the Government calls for intersectoral collaboration that includes the sports sector, there are few concrete guidelines for how this may be implemented in practice. Guided by The Bergen Model of Collaborative Functioning, the purpose of this study was to explore factors that promote or inhibit collaboration in an intersectoral project involving the sports sector, NGOs, and public sector. The current project aimed to work towards creating health promoting activities aimed at vulnerable youths. Methods: A qualitative case study of the Sports Project with interviews of eleven collaborative partners. Results: Factors promoting collaboration amongst the different partners were having a common mission, an appreciation of the partners' complementary skills and knowledge, and a consistent user perspective. Conclusions: By orienting the collaboration towards the users' needs, the partners have succeeded in creating tailored health-promoting activities for vulnerable youths. However, a challenge remains in transforming the collaborative project into a sustainable structure.
\end{abstract}

Keywords: intersectoral collaboration; sports sector; health promotion; collaboration; vulnerable youths

\section{Introduction}

Mental health and physical inactivity have been identified as major public health challenges facing youths today [1]. Young people with mental health issues can be at risk for drug use, which is detrimental to well-being and overall health from a lifetime perspective [1]. However, factors influencing public health challenges are often complex and without a clear solution. Within the field of health promotion, the Social Determinants of Health Model highlights this complexity by emphasizing that health is created through an interaction between the individual and the surrounding environment, such as the socioeconomic conditions, the physical environment, and social support networks [2]. Consequently, rather than the health sector alone, all sectors of society play an essential role in supporting healthy lives [3-5].

The ratification of the Norwegian Public Health Act is considered the clearest example of a health-promoting policy by solidifying the municipalities' responsibility to promote health, demanding a high degree of intersectoral collaboration [6,7]. Additionally, the Public Health Act emphasizes that the municipality should collaborate with NGOs to promote health. NGOs, especially the sports sector, are seen as a significant resource for promoting health locally $[8,9]$.

Most of the research literature on local health promotion and collaboration has been devoted to describing how municipalities face the challenges associated with intersectoral 
collaboration [10-14]. Previous research has demonstrated that the sports sector has successfully been used as a tool for promoting health through reaching vulnerable groups, creating social inclusion, integrating refugees, preventing crime, and addressing other complex public health challenges [15-18]. However, research shows that achieving fruitful collaboration between different organizations and sectors is challenging. Sports clubs and other NGOs are considered a valuable part of the local health promotion work. Still, limited research explores the collaborative relationship between local partners within the public sector and sports clubs. There are also few concrete guidelines for implementing this in practice.

The present study systematically investigates an established intersectoral healthpromoting collaborative project to strengthen vulnerable youths. The concept "vulnerable groups" often refers to people needing support with social, health, and economic problems [19]. The youths at the center of the present study have been recruited to the sports project by health and welfare services, based on their experiences with drug abuse and/or mental health issues. Virokannas and colleagues [19] argue that attention needs to be directed both towards the structures and social processes that add to the vulnerability and to processes aimed at empowering the vulnerable youth. Concepts such as "youth with complex needs" [20], "young person not in employment, education or training (NEET)" [21], "youth in flight" [22], and many more aim to capture the group of youths who fall into the category of vulnerable youth. While the concept of vulnerable youth focuses on the vulnerability of youth and can be said to be rooted in a "pathogenic tradition", the present study focuses on factors that promote health for the youths. The following study aims to explore a collaborative initiative between local partners motivated by creating health-promoting activities to strengthen the youths engaged in the project.

\subsection{Bergen Model of Collaborative Functioning}

Models can be helpful to explore factors influencing collaboration and understand the mechanisms involved. The Bergen Model of Collaborative Functioning (BMCF) has previously been used to examine various partnerships [23-27]. The BMCF is a model that examines elements and dynamics of functioning as input, throughput, and output [26]. The inputs are the mission, partner resources, and financial resources. Throughput involves two types of tasks: production activities and maintenance activities. Four elements impact throughput functioning: leadership, communication, roles/structure, and input interaction. These elements create cycles of positive or negative interactions that contribute positively to collaborative functioning or detract from it. The three outputs are additive results (not impacted), synergy (positive), and antagony (negative) [26]. Following is an illustration of the Bergen Model of Collaborative Functioning (Figure 1: The Bergen Model of Collaborative Functioning).

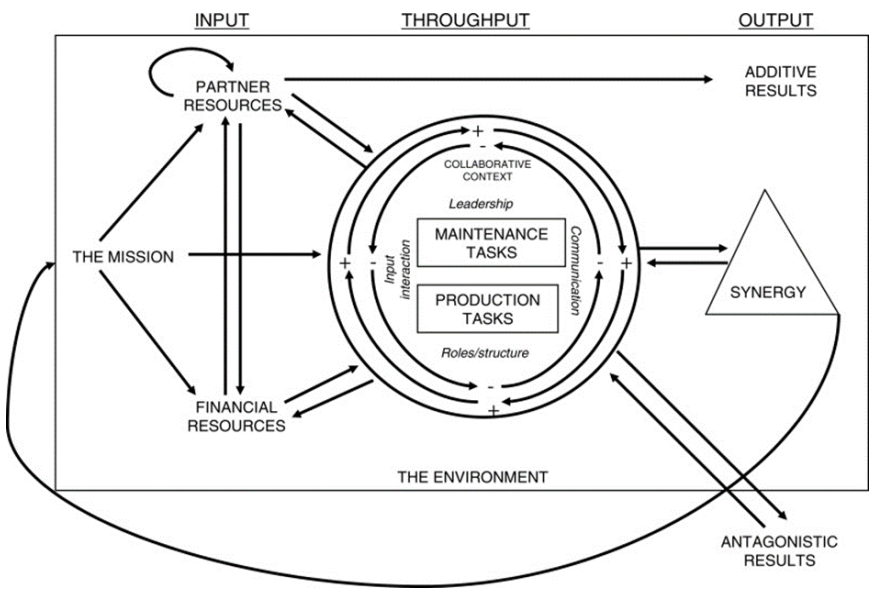

Figure 1. The Bergen Model of Collaborative Functioning [26]. 


\subsection{Aim of the Study}

Guided by the Bergen Model of collaborative functioning, the present study seeks to explore an established collaborative project between sports organizations, NGOs, and the public sector to promote health for youths who have had problems with drug abuse and/or mental health issues. The research question explored in the study is, what factors do the partners identify as promoting or inhibiting for the collaborative project?

\section{Materials and Method}

The present study is designed as a qualitative single case study. Inspired by Yin [28], we chose to investigate the current case due to its unique trait of being a sports project with partners from NGOs, the sports sector, and the public sector devoted to promoting health aimed at youths at risk.

\subsection{The Sports Project}

The sports project was implemented by five sports clubs that have established an organization to create health-promoting activities for vulnerable groups to reduce socioeconomic inequalities within the local community. This organization, referred to as The Main Organization, has four full-time employees who coordinate various health-promoting projects in collaboration with the sports clubs, the municipality, and the NGOs. The Main Organization runs the activities and is led by a board consisting of the sports leaders from the five different sports clubs.

The specific target group for this sports project is young people who have had problems with drug abuse and/or mental health issues. To get essential knowledge and contact with the youths, The Main Organization collaborates with various partners and sectors involved with this specific group. The different collaborative partners involved in the project are organized into two main categories: the public sector (police, child welfare services, municipal outreach service, psychiatric treatment center, and exercise therapy) and NGOs (Red Cross, inmates return to society center, motivation center). The partners are responsible for recruiting youths to the project and contributing with their knowledge about the target group. Together the partners develop activities and a social meeting place to promote physical activity and personal development for the vulnerable youth. The following illustration present the partners of the collaborative project (Figure 2: Illustration of the partners of the sports project).
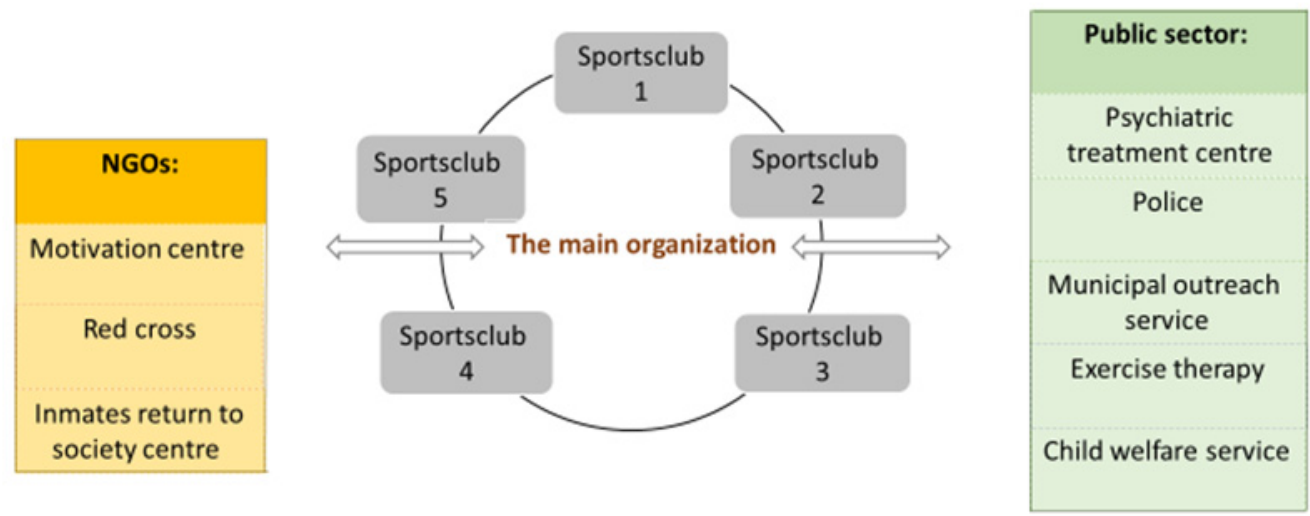

Figure 2. Illustration of the partners of the sports project.

\subsection{Participants and Procedure}

The data were collected through individual interviews with 10 out of 13 partners from the collaborative group. A strategic sampling strategy was used to recruit the informants [29]. Observations of several activity sessions and collaboration meetings were also made. The sample consisted of three informants from The Main Organization, four informants from NGOs (Red Cross, motivation center, inmates return to society center), 
and three from the public sector (psychiatric treatment center, police, and a municipal outreach service).

The interviews were conducted in the fall of 2018. With permission from the informants, all interviews were recorded and transcribed verbatim shortly after each interview. The interviews each lasted between 45 and $90 \mathrm{~min}$. The questions were open-ended to enable the informants to speak freely, e.g., How did you get into this collaborative project? What role do you have in the collaboration group? How has the work evolved during the time you have worked on the project?

The interviews were analyzed by using thematic analysis, in which the study depicts the main features of the data material [30]. A combination of inductive and deductive approaches was used. Braun and Clark's [30] six-step thematic analysis method was used, and the codes were categorized into various themes following the BMCF. All of the informants signed informed consent forms before the interviews. To ensure informants confidentiality, name, gender, age, and city are not mentioned. The Norwegian Centre for Research Data approved the study.

\section{Results}

The results of this study are presented according to the elements of the BMCF and follow three categories relevant to the data: input (elements entering into the partnership), throughput (processes within the partnership), and output (the result) [26].

\subsection{Input Phase}

The Main Organization had the overall responsibility for planning the project, but several partners were involved. The informants described the involvement in the planning process as an essential factor in promoting the partners' sense of ownership of the project.

The starting point of the BMCF is the mission, which refers to the common goal of the collaborative project. The informants described similar aims for the collaboration and related their commitment to the sports project to its mission. To have a common goal was something that all informants defined as necessary, and a majority said it was the most crucial factor for the collaboration to achieve synergy.

"We all want the same thing. We work with drug and crime prevention. We want to prevent people from continuing in such a career. This is something that the public sector also wants. So I guess we all work for the same goal. We will have a safer society if this group can get away from drugs and crime through activity and new interests. Therefore, I reckon that everyone has a common goal; To prevent this through activities." (Informant, NGO)

"I feel that everyone knows that these young people need an arena, they need a safe place where they can cope... and that is a common goal for all partners. So the goal is the same, but we have different networks where we meet the youth and bring them to the project. It appears relatively ... homogeneous: a common goal." (Informant, Public sector)

The informants also described secondary interests as to why they joined the collaboration. The informants from the sports clubs highlighted their lack of knowledge about the target group as a motivating factor to collaborate with professionals who had that knowledge. Others mentioned collaboration itself as a driving factor. The Main Organization emphasized that physical activity was not a goal itself, but a tool:

"The activity itself is secondary. My job is not to get the youth in the best possible physical shape. My job is about everything that happens around the activity" (Informant, Main Organization)

Following the BMCF, another input to the collaborative process is partner resources. The informants described several individual, organizational, and financial resources as important. Partner resources mentioned were knowledge, networks, skills, time, and commitment. Most of the partners also described the collaboration as a place to exchange experiences and knowledge. The partners involved in recruiting youth emphasized The 
Main Organization's competences in the activity offered and the coordinator's interaction with the youth. One informant described:

"For us, it is important to know that my patients will be taken care of. To join the activity is considered a big risk for the youth here. And if they do not feel welcome, it is almost worse than if they did not go at all. So the consequences are high." (Informant, Public sector)

The coordinators in the Main Organization emphasized that their knowledge about sport and activity was not enough to create an activity that was adapted to the target group's needs. They also needed knowledge from the professionals.

"When we work with such a complex target group, we have to consider multiple factors. (... .). We have a lot of knowledge about activity and sport, but there is so much more to consider in this case. We need the knowledge from the professionals who work with this group." (Informant, Main Organization)

How much time each partner invested in the collaboration varied considerably. The Main Organization's representatives who coordinated the project spent a lot of time on it and described themself as "the engine of the project".

"Our partners are busy with hectic workdays, which makes it hard to plan meetings. It is a challenge for the collaboration group to grow." (Informant, Main Organization)

One informant described the anchoring of the collaboration on the leadership level of the organizations as essential for a successful collaboration. Without support from the leadership for participation and allocation of time, it was considered impossible to collaborate. Recruiting youth into the project was one of the most critical tasks for most of the partners in the project. Getting in touch with the target group was described as complicated by The Main Organization, especially when working preventively with youth who were not in contact with a rehabilitation center or psychiatric treatment center.

Another input described by the BMCF was the financial resources of the partners. Resources to maintain the collaborative practice came mainly from fundings that The Main Organization applied for. Although this was an extensive job, it eased the collaboration for the partners:

"I believe that it is easier to cooperate with us because we "take care of" the financial part. When it comes to questions about finances, there are many who do not have the opportunity to contribute. Collaboration also becomes more complicated with a shared budget" (Informant, Main Organization)

In general, many of the partners had experienced it as financially challenging to collaborate in such projects. Without a permanent organizational structure, financing tended to be unpredictable. Therefore, The Main Organization invested a lot of resources in obtaining and reporting on finances. Most of the informants emphasized that fortunately, the target group of the sports project is considered a relevant and important priority for public health. This was also highlighted when The Main Organization applied for funding. One informant described the process of attaining fundings as quite achievable:

"When you have good projects and projects with high relevance, it's easier to apply for financial support. And this (the project) is something that people are passionate about."

(Informant, Main Organization)

Those representing The Main Organization experienced it as more easily to receive funding than the individual sports clubs. Creating an organization with a health promotion perspective was perceived as an essential factor for receiving the funding. In addition, the five sports clubs behind The Main Organization had savings to provide financial support for permanent positions for the coordinators. Thus, the employees' financial security was considered one central success factor for the project. 
"It is important to show the employees that if the fundings we apply for will not come, we have a buffer. The sports sector often provides jobs that are not secure, and a lot of work is done voluntarily. But we expect more from the coordinators in the main organization, and that's why it's important to give more." (Informant, Main Organization)

\subsection{Throughput Phase}

The factors that impacted the collaborative practice process were communication, trust, structure and roles, maintenance, and practical issues. The combination of inputs (the mission, partner resources, and financial resources) and how they interact is referred to as input interaction. Several informants believed that the interaction between the people in the collaborative project motivated people to participate. Primarily the cooperating meetings were emphasized as meaningful and positive for the collaboration.

"It is a place where you feel that you can contribute. Together you get this ownershipfeeling of the project. You can see the others, and people are listening to what you say." (Informant, Public sector)

Factors that facilitated this collaboration included thorough planning, good interaction between inputs, committed leadership, trust between partners, clear structures and roles, and good communication. The partners communicated by telephone, email, and face-toface in meetings. All the informants believed face-to-face communication was the most productive when collaborating in the sport project. The meetings provide a place where partners could get to know one another and develop trust. Trust was described as especially important by the partners who recruited youths to the activities. The leadership from The Main Organization described a high degree of trust with the partners and they believed that they also were trusted:

"When you bring in patients with different problems to us, there is a risk associated with that (...) So when we experience partners such as institutions and clinics bringing youths and patients to us regularly, I hope that it is an indication that we are doing a good job and that they trust us." (Informant, Main Organization)

One potential inhibiting factor for the collaboration was that the roles and responsibilities were perceived differently among the partners. Both the informants from the public organizations and the NGOs expressed that the NGOs are in general more eager to collaborate than the public sector. The informants expressed that the NGOs wanted to strengthen each other through collaboration. The public sector, on the other hand, are rule-bound and not as flexible, challenging the collaboration process. One informant from the public sector expressed it in the following way:

"You have to be somewhat altruistic and pragmatic going into a collaboration such as this, but the public sector is pretty rigid: "this is our responsibility, and this is not our responsibility." If the patient is admitted, they can handle the expenses, but the municipality has to "take it" if the patient quits. And if you are constantly thinking in these rigid ways, the collaboration doesn't work. Or it becomes challenging to collaborate." (Informant, Public sector)

Nevertheless, the contribution from "key people" in the project, especially those working in The Main Organization, enhanced the collaboration and had a compensating role. The informants considered that the success of the project was dependent on these individuals, who were characterized as being open, including, trusting, professional, skillful, engaged, structured, and organized. One informant said:

"They have skilled people working there. They are extremely engaged who work to become better. People who start projects often get lazy, but not these people. They have been devoted to their work." (Informant, NGO) 


\subsection{Output Phase}

In the interviews, the informants expressed how they achieved more through the collaborative project than they would do independently. All informants experienced the collaboration as fruitful and the activities they offered youths as important. The alternative would be to contact sport clubs directly, which could be challenging. The Main Organization expressed that they would not have been able to reach the target group without the recruiting partners:

"We would not have been able to find the people who are with us today if it had not been for the collaboration. ( ... ) Without the collaboration, nothing would have happened" (Informant, Main Organization)

Beyond achieving the goals of providing vulnerable youths with activities, the sports project also resulted in other outcomes. One informant said:

"One thing is that the partners of the collaboration regularly meet during the project., but it may also contribute to the partners getting a better collaboration and knowledge about each other in other contexts. We can see that during our meetings, other ideas and collaborations come up." (Informant, Main Organization)

The collaboration was described as an arena where you could create a network and show your organization.

"Some of those participating in the collaboration want to create a network. Some partners are relatively new (...) But it does not overshadow the goal of this collaborative project. But they have "side-goals," where the collaboration can help them in raising awareness for their organization." (Informant, Main Organization)

The informants described how the collaboration between partners increased through the sports project, especially between the different sports clubs. One informant explained how the sports clubs had identified common ground and felt stronger together as a combined group.

"It is unique for the collaboration that five sports clubs have come together to collaborate about this. And by doing so, we have created an arena for us to discuss other issues. It makes us stronger." (Informant, Main Organization)

Informants from the NGOs described the opportunity to recruit youth to become volunteers as an additive result of the collaboration. This was described as a positive effect of the partnership and as a "win-win situation."

"After a while, more participants could volunteer here. Because many want to contribute and that is nice. It becomes a win-win situation where they can fill their days with something meaningful, and we get new volunteers." (Informant, NGO)

Informants from the public sector said the collaboration also gave them knowledge of other activities organized by NGOs.

\section{Discussion}

This study aimed to explore the promoting and/or inhibiting factors of an intersectoral collaborative health-promoting project involving the sports sector. Guided by the Bergen Model of Collaborative Functioning, the study identified the collaborative partner's perception of a unified understanding of the mission and goal as crucial for establishing and maintaining the collaboration. They were all aligned in the importance of promoting health for vulnerable youths through activities, an aim that the partners experienced as complex and multifaceted. They also shared an understanding of the importance of having a user perspective in forming the project and developing the activities. In addition, the informants described secondary interests, which also supported the collaboration, such as creating networks. The collaborative partners were considered resourceful within their respective areas. This experience built trust and dependency between the partners. Roles 
and responsibilities were firmly anchored, giving the collaboration a well-defined structure. The Main Organization as a driving and coordination force of the project was especially emphasized. The collaboration required a degree of altruism, mainly attributed to the partners from the NGOs, to compensate for a more rigid public sector. In addition to describing the collaboration as a success in providing well-functioning activities for vulnerable youths, the partners identified additive results of the collaboration. Finally, the partners explained that the collaboration itself had increased their knowledge of each other and had extended the partnership into new areas. Overall, the study findings align with the many elements and dynamics identified in the Bergen Model of Collaborative Functioning as essential for a fruitful collaboration between stakeholders.

\subsection{The Value of a Common Mission and Goal}

A key finding was how the different partners described the goal and mission. They were all aligned in the importance of providing a health-promoting activity for young people who have problems with drug abuse and/or mental health issues. The informants descriptions of the common goal were comprehensive and overarching. The descriptions were similar, almost identical, among the partners. It also emerged from the analysis that the partners shared a common understanding of challenges vulnerable youth face and how to strengthen the youth. This positively affected collaboration. Both BMCF and several studies describe a common goal as crucial for collaboration [27,31-36]. The shared goal reflected a mutual awareness of the existing public health challenges and health promotion as a shared responsibility for all societal sectors, reflecting the need for intersectoral collaboration.

The BMCF emphasizes that the collaboration goal and mission affect the partner's motivation to participate, and studies show that partners need concrete motivational factors to enter into a collaborative project [32,37]. The findings from the present study support this as the concern for the project's target group was the main motivational factor for participating in the sports project. The analysis showed that the partners wanted to support the target group since youth with substance abuse and mental health issues often fall between the cracks of the Norwegian welfare system and are perceived as marginalized. It is problematic that the public organizational structures fail to meet the users' needs. Therefore, providing comprehensive services is one of the Coordination Reform goals in Norway [38]. The findings show that the project's relevance strongly influenced the shared mission of aiding the target group.

In addition to the shared mission and goal, the analysis highlighted the partner's other goals for the individual organization, such as networking. Corbin and colleagues [27] emphasize that it is essential to develop collaborations to grow and improve. The common problem is that a group may become too occupied by the collaboration results and neglect the collaborative functioning and the needs of the different partners. For example, a Swedish report showed that approximately $90-95 \%$ of the time, financial resources, competency, and attention in collaborative projects are devoted to achieving the goals of the project, while $5-10 \%$ are devoted to ways to benefit the lessons learned from the collaborations [39]. Interestingly, The Main Organization specified that the collaborative process was a goal in itself for them. This may have created awareness and attention to ways of benefiting from the collaborative process. The experiences from the present study suggest that the different partner's "side-goals" can play an essential role in motivating the partners for the collaboration in itself and the common goal of the collaborative functioning.

\subsection{The Value of Complementary Skills and Roles}

Like Corwin's study [31], the partners and their network were the most meaningful factors invested in the sports project. In all interviews the importance of "key people" and the project's dependence on individuals was mentioned. Previous studies have identified these factors as both promoting and inhibiting the collaboration [40-42]. The present study's findings highlight the partners' appreciation of the diverse resources and complementary 
knowledge. The informants from The Main Organization highlighted that the project was created due to their limited knowledge about the target group. As an informant explained, financial resources and engagement were not enough to aid the youths. BMCF indicates that the resources invested in a collaborative project determine what competence the project has access to during the process. In several studies, diversity is highlighted as contributing to varied and comprehensive competence [36,43]. For example, Hermens and colleagues [43] saw that multiple competence exchanges led to synergistic results because the participating partners covered each other's shortcomings. This was also prominent among the informants in this study. The diversity of the project can be seen as a promoting factor for the success of the collaboration. The findings show that The Main Organization practiced an inclusive planning strategy where they invited several partners to the planning phase to increase the feeling of ownership for the project. In the LIPSE-study (Learning from Innovation in Public Sector Environments) from 11 European countries and 7 policy sectors, the sense of ownership of the collaborative project is highlighted as a significant factor in all countries [32]. In the present study, feeling ownership was important for commitment and motivation.

The BMCF and several studies emphasize that a collaboration project needs to be relevant for today's society to gain access to resources needed to create a successful collaboration $[26,32,43,44]$. The informants in the present study defined both physical activity and the target group as important. In line with the study of Corbin and Mittelmark [26], the informants said the relevance of the project simplified recruitment of collaboration partners and financing. To secure the funding may be extra important for collaborative projects that include the sports sector since several studies have reported that the sports sector often works with insecure funding conditions [35,45]. The five sports clubs that created the organization had extra economic resources to ensure financial security and offer the coordinators in The Main Organization full-time employment. Thus, the findings show that financial security can be essential for the project's sustainability and collaborative functioning.

\subsection{The Value of the User Perspective}

The present study highlights the importance of a common mission motivating the partners to collaborate to create health-promoting activities aimed at vulnerable youths struggling with mental health issues and/or substance abuse. The sports project was strengthened by an appreciation of each partner's contribution to either creating the activity, organizing the activity, or recruiting the youths to the activity. Therefore, a central feature of the collaboration was the consistent focus on the target group. This was also reflected in the choice of activity organized for the youths that proved to be of great importance for the success of the sports project. Research shows that vulnerable groups have low participation in sports [46]. Often sports are associated with team sports such as football or basketball, and although there are documented positive effects with team sports, many people do not find their place there $[47,48]$. The target group may face stressors that make it difficult to participate and adapt to a team sport. Research shows that social anxiety, performance anxiety, aggression problems, or anxiety can make team sports activities be perceived as difficult [48]. By selecting climbing as the chosen activity, The Main Organization organized an activity adapting to the needs of the youths, thus having a user-oriented approach.

In the white paper 'Volunteering for all' [49], the Norwegian Government writes that sports' most significant contribution to public health is to create an inclusive environment for different groups in the population. Kaehne [50] has criticized collaborative initiatives for focusing more on interprofessional collaboration and consequently losing sight of what the collaboration should be focused on, namely, the people that the services are intended to assist. By having the needs of the youths as a central aspect of the collaboration, the collaboration has succeeded in making the sports project meaningful. 


\subsection{The Value of Synergies}

BMCF assumes that the interplay between invested factors and factors in the collaboration process leads to different effects or results. Synergy effects can be achieved by the cooperation leading to something more than the organizations could achieve themselves. The present study shows a unanimous opinion among the partners that the goal of the sports project had been achieved, which was due to a well-functioning collaboration. In addition to the overall goal, the present study identified several other collaborative effects. The project meetings, in particular, contributed to the synergy effects of the collaboration. The meetings were an arena where thoughts and ideas were welcome. Discussions could lead to more collaborative projects and more knowledge of each other's organizations and the target group.

Including each organization's additional goals can motivate long-term participation. In the interviews, it emerged that several informants from both the voluntary and public sector encountered resistance and a certain inertia in their encounter with the public sector, something that can be interpreted as a negative or antagonistic effect of collaboration [26]. In Norway there have been long traditions for local collaborations between the public sector and NGOs. Loga and Eimhjell [51] conclude that the form of work is appreciated and recognized in Norway. Findings from the present study show that the public sector was characterized as rule-bound and not as flexible, making them sometimes difficult to collaborate with. This could negatively impact the relationship. The LIPSE-study addressed this issue, reporting a risk-avoiding and conservative culture in the public sector that could reduce the chances of collaboration between the public sector and NGOs [32]. These tensions can deteriorate the collaboration. Research has highlighted a positive attitude between sectors as a promoting factor for intersectoral collaboration [32,34,52]. In the current study it was emphasized that the collaboration required a degree of altruism, which was mainly attributed to the partners from the NGOs, to compensate for a more rigid public sector.

\subsection{Bergen Model of Collaborative Functioning in a New Context}

The BMCF has guided the present study when analyzing the collaborative project between NGOs and the public sector. Although the BMCF is a well-used model, it is applied only in a limited number of contexts. The model was a valuable tool in researching the collaboration, aiding the structuring of questions, and the analysis of the relationships within the collaboration, investigating how the partners influence each other and are influenced by their resources. The present study also identified the added value of each partner's personal "side-goals" of the collaboration. Therefore, an extension to the BMCF could be the inclusion of the partners' individual "side-goals," as a factor that could create more synergies for the involved stakeholders. Nevertheless, this finding may be context specific.

\section{Strengths, Limitations, and Further Research}

The study's goal was to provide insight into how the partners viewed the collaborative project. A strength of the study is that everyone who participated in the sport project was given the opportunity to participate in the interviews. Out of thirteen invited, only two were unable to take part. Involving partners with different roles in the collaboration, gave comprehensive data that strengthened the interpretation of the results. However, as the analysis follows the informant's individual perspective, one possible limitation was that all the informants were positive about the collaboration. Thus, the analysis follows their description of the inhibiting and promoting factors of the collaboration. In addition, the study is of a fairly small scale, with informants from within the project, and therefore the perspective of the users themselves could add valuable knowledge to the findings. Still, important insights of factors promoting collaboration in a cross-sectoral project can be transferable to other contexts. 
While the target group was not a part of the formal collaboration, it would be interesting to further explore how the users of the activities experience the sports project. Further research could also more in-depth examine the perceived effects of the activities. This would allow for a better evaluation of whether the project has been successful in obtaining its intended goal to strengthen the vulnerable youth and promote health and wellbeing.

\section{Conclusions}

The studied sports project is an example of how the society can utilize the resources in the local community through intersectoral collaboration. The study utilized the Bergen Model of Collaborative Functioning to analyze the promoting and inhibiting factors of the sports project. Most of the factors identified as important in BMCF were found to be relevant in the analysis of the empirical material. By orienting the collaboration towards the needs of the users the partners have created tailored health-promoting activities towards youths struggling with mental health issues and/or substance abuse who "fall between the cracks of the public system" and are seldom organized in sports.

The results confirm factors identified in previous studies as important for collaboration processes, but also contribute with new knowledge to the research field. Key factors were considered to be:

Promoting:

- a common goal

- $\quad$ sufficiently invested partner resources, including financial resources

- $\quad$ perceived relevance of the project

- partners with clear roles and responsibilities within the collaboration

- a strong user perspective and user-oriented approach in the activity choice Inhibiting:

- a rule-bound and not as flexible public sector challenging the collaboration process

Through the sports project, The Main Organization and the collaborating partners have shown how sports can be used as a tool in health promotion work for vulnerable groups. Still, a challenge remains in transforming collaborative projects, such as this sports project, into sustainable structures.

Author Contributions: Conceptualization, D.T., T.L. and E.H.; methodology, D.T., T.L. and O.O.; formal analysis, D.T. investigation, D.T.; data curation, D.T.; writing—original draft preparation, D.T.; writing-review and editing, D.T., O.O., T.L. and E.H.; supervision, T.L. and E.H.; project administration, O.O. and E.H.; All authors have read and agreed to the published version of the manuscript.

Funding: This research received no external funding.

Institutional Review Board Statement: Not applicable.

Informed Consent Statement: Informed consent was obtained from all participants involved in the study.

Acknowledgments: We would like to thank the individuals who participated in the interviews and contributed with their experiences.

Conflicts of Interest: The authors declare no conflict of interest.

\section{References}

1. World Health Organization (WHO). Health for the World's Adolescents: A Second Chance in the Second Decade; WHO: Geneva, Switzerland, 2014. Available online: https://www.who.int/maternal_child_adolescent/documents/second-decade/en/ (accessed on 23 November 2021).

2. Dahlgren, G.; Whitehead, M. The Dahlgren-Whitehead model of health determinants: 30 years on and still chasing rainbows. Public Health 2021, 199, 20-24. [CrossRef] [PubMed]

3. Willumsen, E.; Ødegård, A. Tverrprofesjonelt Samarbeid et Samfunnsoppdrag [Intersectoral Collaboration a Societal Mission], 2nd ed.; Universitetsforlaget AS: Oslo, Norway, 2016. (In Norwegian) 
4. World Health Organisation. Health in All Policies (HiAP) Framework for Country Action. Health Promot. Int. 2014, $29,19-28$. [CrossRef] [PubMed]

5. Axelsson, R.; Axelsson, S.B. Samverkan og folkhälsa-begrepp, teorier og praktisk tillämning. In Folkhälsa i Samverkan Mellan Professioner, Organisationer och Samhällssektorer [Public Health in Coordination with Professionals, Organizations and Society]; Axelsson, R., Axelsson, S.B., Eds.; Studentlitteratur: Lund, Sweden, 2007; pp. 11-31. (In Norwegian)

6. Fosse, E.; Helgesen, M. Advocating for health promotion policy in Norway: The role of the county municipalities. Societies 2017, 7, 5. [CrossRef]

7. Ministry of Health and Care Services, Government of Norway; Lov om Folkehelsearbeid [Public Health Act], No. 29, 24-06-2011 2011. Available online: https://lovdata.no/dokument/NL/lov/2011-06-24-29 (accessed on 19 February 2021).

8. Aarø, L.E.; Klepp, K.I. Ungdom, Livsstil og Helsefremmende Arbeid [Youth, Lifestyle and Health Promotion], 4th ed.; Gyldendal Norsk Forlag AS: Oslo, Norway, 2017. (In Norwegian)

9. Folkestad, B.; Christensen, D.A.; Strømsnes, K.; Selle, P. Frivillig Innsats i Noreg 1998-2014. In Kva Kjenneteikner dei Frivillige og Kva har Endra Seg? [Voluntary Effort in Norway: What Characterizes NGOs and What Has Changed?]; Rapport 4/2015; Senter for Forskning på Sivilsamfunn og Frivillig Sektor: Oslo, Norway, 2015. (In Norwegian)

10. Larsen, M.; Rantala, R.; Koudenburg, O.A.; Gulis, G. Intersectoral action for health: The experience of a Danish municipality Scand. J. Public Health 2014, 42, 649-657. [CrossRef] [PubMed]

11. Holt, D.H.; Frohlich, K.L.; Tjørnhøj-Thomsen, T.; Clavier, C. Intersectoriality in Danish municipalities: Corrupting the social determinants of health? Health Promot. Int. 2016, 32, 881-890. [CrossRef]

12. Synnevåg, E.; Amdam, R.; Fosse, E. Intersectoral planning for public health: Dilemmas and Challenges. Int. J. Health Policy Manag. 2018, 7, 982-992. [CrossRef]

13. Oldeide, O.; Fosse, E.; Holsen, I. Collaboration for drug prevention: Is it possible in a "siloed" governmental structure? Int. J. Health Plan. Manag. 2019, 34, e1556-e1568. [CrossRef] [PubMed]

14. Oldeide, O.; Fosse, E.; Holsen, I. Local drug prevention strategies through the eyes of policy makers and outreach social workers in Norway. Health Soc. Care Commun. 2020, 29, 376-384. [CrossRef]

15. Fahlén, J.; Stenling, C. Same same, but different? Exploring the organizational identities of Swedish voluntary sports: Possible implications of sports clubs' self-identification for their role as implementers of policy objectives. Int. Rev. Sociol. Sport 2016, 5, 867-883. [CrossRef]

16. Hartmann, D. Midnight Basketball: Race, Sports, and Neoliberal Social Policy; The University of Chicago Press: Chicago, IL, USA, 2016.

17. Norberg, J.R. A contract reconsidered? Changes in the Swedish state's relation to the sports movement. Int. J. Sport Policy Politics 2011, 3, 311-325. [CrossRef]

18. Hermenes, N.; Koelen, M.A.; Verkooijen, K.T. Associations between partnership characteristics and perceived success in Dutch sport-for-health partnerships. Sport Manag. Rev. 2019, 22, 142-152. [CrossRef]

19. Virokannas, E.; Liuski, S.; Kuronen, M. The contested concept of vulnerability-A literature review. Eur. J. Soc. Work 2020, 23, 327-339. [CrossRef]

20. Almqvist, A.L.; Lassinantti, K. Social work practices for young people with complex needs: An integrative review. Child Adolesc. Soc. Work J. 2018, 35, 207-219. [CrossRef]

21. Lögdberg, U.; Nilsson, B.; Kostenius, C. “Thinking about the future, what's gonna happen?" How young people in Sweden who neither work nor study perceive life experiences in relation to health and well-being. Int. J. Qual. Stud. Health Well-Being 2018, 13, 1422662. [CrossRef] [PubMed]

22. Follesø, R. Youth at risk or terms at risk? YOUNG 2015, 23, 240-253. [CrossRef]

23. Corbin, J.H.; Fernandez, M.E.; Mullen, P.D. Evaluation of a community-academic partnership: Lessons from Latinos in a network for cancer control. Health Promot. Pract. 2015, 16, 345-353. [CrossRef] [PubMed]

24. Corbin, J.H.; Mittelmark, M.B.; Lie, G.T. Grassroots volunteers in context: Rewarding and adverse experiences of local women working on HIV and AIDS in Kilimanjaro, Tanzania. Glob. Health Promot. 2015, 23, 72-81. [CrossRef] [PubMed]

25. Corbin, H.; Corwin, L.; Mittelmark, M.B. Producing synergy in collaborations: A successful hospital innovation. Innov. J. Public Sect. Innov. J. 2012, 17, 1-16.

26. Corbin, J.H.; Mittelmark, M.B. Partnership Lessons from The Global Programme of Health Promotion Effectiveness: A Case Study. Health Promot. Int. 2008, 23, 365-371. [CrossRef] [PubMed]

27. Corbin, J.H.; Jones, J.; Barry, M.M. What makes intersectoral partnerships for health promotion work? A review of the international literature. Health Promot. Int. 2016, 33, 4-26. [CrossRef]

28. Yin, R.K. Case Study Research: Design and Methods, 5th ed.; Sage: Thousand Oaks, CA, USA, 2014.

29. Malterud, K. Kvalitative Metoder for Medisin og Helsefag [Qualitative Methods for Health Sciences], 4th ed.; Universitetsforlaget: Oslo, Norway, 2017. (In Norwegian)

30. Braun, V.; Clarke, V. Using thematic analysis in psychology. Qual. Res. Psychol. 2006, 3, 77-101. [CrossRef]

31. Corwin, L. Factors and Processes that Facilitate Collaboration in a Complex Organisation: A Hospital Case Study. Master's Thesis, University of Bergen, Bergen, Norway. Available online: https://bora.uib.no/bora-xmlui/handle/1956/4453 (accessed on 19 February 2021).

32. Voorberg, W.H.; Trummers, L.; Bekkers, V.; Torfing, J.; Tonurist, P.; Kattel, R. Co-Creation and Citizen Involvement in Social Innovation: A Comparative Case Study Across 7 EU-Countries; LIPSE Report; EU Commission: Brussels, Belgium, 2015. 
33. Cook, A. Partnership Working across UK Public Services Edinburgh: What Works Scotland. 2015. Available online: http:// whatworksscotland.ac.uk/wp-content/uploads/2015/12/WWS-Evidence-Review-Partnership-03-Dec-2015-.pdf (accessed on 23 November 2021).

34. Ekmann, L.; Siversten, H.; Stene, M.; Lysø, R. Samarbeid for Barn og Unges Oppvekstmiljø [Collaboration for Children and Youths]; Erfaringer Fra Samarbeid Mellom Kommune og Frivillighet i STEINKJER Kommune; TFoU-Rapport 2017:07; Trøndelag Forskning og Utvikling AS: Trondheim, Norway, 2017. (In Norwegian)

35. Casey, M.M.; Payne, W.R.; Brown, S.J.; Eime, R.M. Engaging community sport and recreation organisations in population health interventions: Factors affecting the formation, implementation, and institutionalisation of partnerships efforts. Ann. Leis. Res. 2009, 12, 129-147. [CrossRef]

36. Estacio, E.V.; Oliver, M.; Downing, B.; Kurth, J.; Protheroe, J. Effective Partnership in Community-Based Health Promotion: Lessons from the Health Literacy Partnership. Int. J. Environ. Res. Public Health 2017, 14, 1550. [CrossRef] [PubMed]

37. Voorberg, W.H.; Bekkers, V.; Tummers, L. Co-Creation in Social Innovation: A Comparative Case-Study on the Influential Factors and Outcomes of Co-Creation 2014, Department of Public Administration, Rotterdam. Available online: https://core.ac.uk/ download/pdf/20116379.pdf (accessed on 23 November 2021).

38. Ministry of Health and Care Services, Government of Norway. The Coordination Reform, St. Meld nr 47 2008-2009; Departementenes Servicesenter: Oslo, Norway, 2009.

39. Jensen, C.; Trägårdh, B. Temporära Organisationer för Permanenta Problem, Skrifter Från Temagruppen Unga i Arbetslivet 2012, Stockholm, Temagruppen Unga. 2012. Available online: http:/ / www.temaunga.se/sites/default/files/Rapporter/temporara_ mini.pdf (accessed on 19 February 2021).

40. Jones, J.; Barry, M.M. Exploring the relationship between synergy and partnership functioning factors in health promotion partnerships. Health Promot. Int. 2011, 26, 408-420. [CrossRef] [PubMed]

41. Eriksson, C.C.G.; Fredriksson, I.; Fröding, K.; Geidne, S.; Pettersson, C. Academic practice-policy partnerships for health promotion research: Experiences from three research programs. Scand. J. Public Health 2014, 42, 88-95. [CrossRef] [PubMed]

42. Dennis, S.; Hetherington, S.A.; Borodzicz, J.A.; Hermiz, O.; Zwar, N.A. Challenges to establishing successful partnerships in community health promotion programs: Local experiences from the national implementation of healthy eating activity and lifestyle (HEAL[TM]) program. Health Promot. J. Aust 2015, 26, 45-51. [CrossRef] [PubMed]

43. Hermens, N.; de Langen, L.; Verkooijen, K.T.; Koelen, M.A. Co-Ordinated action between youth-care and sports: Facilitators and barriers. Health Soc. Care Commun. 2017, 25, 1318-1327. [CrossRef]

44. Storm, I.; den Hertog, F.; van Oers, H.; Schuit, A.J. How to improve collaboration between the public health sector and other policy sectors to reduce health inequalities?-A study in sixteen municipalities in the Netherlands. Int. J. Equity Health 2016, 15, 97. [CrossRef] [PubMed]

45. Jones, G.J.; Edwards, M.; Bocarro, K.; Bunds, J.; Smith, W. Collaborative Advantages: The Role of Interorganizational Partnerships for Youth Sport Nonprofit Organizations. J. Sport Manag. 2017, 31, 148-160. [CrossRef]

46. Ministry of Culture, Rapport fra Strategiutvalget for Idrett: Statlig Idrettspolitikk Inn i en ny Tid [Governmental Sports Politics in a New Era]. Rapport 6/2016. 2016. Available online: https:/ /www.regjeringen.no/contentassets/3ab984dc671847bebe9a1cd2ec1 $1 \mathrm{f0ec}$ statlig-idrettspolitikk-inn-i-en-ny-tid.-rapport-fra-strategiutvalg-for-idrett.pdf (accessed on 23 November 2021).

47. Kokko, S.; Torp, S.; Ringsberg, K.C.; South, J. Health promotion by communities and in communities: Current issues for research and practice. Scand. J. Public Health 2014, 42, 82-87. [CrossRef]

48. Vandermeerschen, H.; Vos, S.; Scheerder, J. Who's joining the club? Participation of socially vulnerable children and adolescents in club-organised sports. Sport Educ. Soc. 2015, 20, 941-958. [CrossRef]

49. Ministry of Culture and Church, Government of Norway. Volunteering for All, Meld. St. 39 2007-2008; Departementenes Servicesenter: Oslo, Norway, 2008.

50. Kaehne, A. Integration as a scientific paradigm. J. Integr. Care 2017, 25, 271-279. [CrossRef]

51. Loga, J.; Eimhjellen, I. Nye Samarbeidsrelasjoner Mellom Kommuner og Frivillige Aktører-Samskaping i Nye Samarbeidsforhold? [New Collaborative Relations Between Municipalities and NGOs_Cocreation in New Collaborations]; Rapport 2017/9; Senter for Forskning på Sivilsamfunn og Frivillig Sektor, Institutt for Samfunnsforskning: Oslo, Norway, 2017; ISBN 9788277635781. Available online: https:/ / hvlopen.brage.unit.no/hvlopen-xmlui/handle/11250/2592124 (accessed on 23 November 2021).

52. Guribye, E. Mot 'Kommune 3.0'? Modeller for Samarbeid Mellom Offentlig og Frivillig Sektor: Med Hjerte for Arendal [Models for Collaboration Between the Public and NGOs], FoU-Rapport nr.3/2016; Agderforskning Kristiansand: Kristiansand, Norway, 2016; ISBN 9788276022674. 